\title{
ECOLOGY AND BIOLOGY OF GYRFALCONS IN GREENLAND
}

\author{
Kurt K. BURnham ${ }^{1,2,3}$ AND William A. Burnham ${ }^{2, \wedge}$ \\ ${ }^{1}$ Edward Grey Institute of Field Ornithology, Department of Zoology, University of Oxford, \\ South Parks Road, Oxford, OX1 3PS, UK \\ ${ }^{2}$ The Peregrine Fund, 5668 West Flying Hawk Lane, Boise, ID 83709, USA \\ ${ }^{3}$ High Arctic Institute, $60310^{\text {th }}$ Avenue, Orion, IL 61273, USA (current address). \\ E-mail: kburnham@higharctic.org \\ ${ }^{\wedge}$ Deceased
}

\begin{abstract}
We studied two breeding populations of Gyrfalcons (Falco rusticolus) approximately 1,200 km apart in Greenland. During 1998-2006, we collected data from a population in the central-west (Kangerlussuaq), and during 1994-2006 and 2008-2010 from a population in the northwest (Thule). Gyrfalcons in Kangerlussuaq bred approximately 18 days earlier than those in Thule, with egg laying, on average, starting on 17 April and 5 May, respectively. Reproduction was similar between areas, with no significant difference between the number of young produced at occupied or successful nests. Years in which the Kangerlussuaq population bred later showed fewer successful nests, while the lay-date advanced significantly for the Thule population during this study. Diet varied between areas, with the more coastal population in Thule feeding primarily on Dovekies (Alle alle) and the more inland Kangerlussuaq population feeding primarily upon Rock Ptarmigan (Lagopus muta) and passerines. Plumage color in Thule was $>99 \%$ white, while nearly equal numbers of white and grey adults were observed in Kangerlussuaq. No changes in plumage color were observed in Kangerlussuaq from the 1950s onward; however, an unexplained difference in plumage color between sexes was documented during this study. The Gyrfalcon population in Thule appeared relatively stable, whereas the Kangerlussuaq breeding population was likely cyclical, and possibly declining since the early 1990s. Based on the relatively long-term data sets available, these populations are ideal for continued monitoring to determine what effects future climate change may have on Gyrfalcon populations. Received 6 April 2011, accepted 20 July 2011.

Burnham, K. K., AND W. A. BuRnham. 2011. Ecology and biology of Gyrfalcons in Greenland. Pages 1-20 in R. T. Watson, T. J. Cade, M. Fuller, G. Hunt, and E. Potapov (Eds.). Gyrfalcons and Ptarmigan in a Changing World, Volume II. The Peregrine Fund, Boise, Idaho, USA. http://dx.doi.org/10.4080/gpcw.2011.0209
\end{abstract}

Key words: Gyrfalcon, Greenland, Peregrine Falcon, nesting chronology, cyclic population, prey, reproduction. 
GYRFALCONS (Falco rusticolus) have historically been reported breeding along much of Greenland's ice-free coastlines from Peary Land $\left(83^{\circ} \mathrm{N}\right.$ : Manniche 1910, Koch 1925, Johnsen 1953) to Kap Farvel $\left(60^{\circ} \mathrm{N}\right.$ : Rafn 1933, Salomonsen 1950) at the southern tip (Figure 1). Most records were of sightings made and specimens collected prior to 1950 . In the Zoological Museum, Copenhagen, Denmark, there are more than 429 Gyrfalcon specimens that were collected in Greenland alone, primarily to investigate variation in plumage color. Gyrfalcons were commonly shot and/or noted during polar expeditions and collecting trips (e.g., Sabine 1819, Walker 1860, Hall 1876, Hagerup 1891, Stone 1895, Chapman 1899). Explorers and collectors documented locations where falcons were observed breeding or migrating and helped to establish the range and migration timing of the species in Greenland.

Beyond these records from early explorers, little information exists on Gyrfalcons in Greenland other than the occasional anecdotal mention in the literature and observations collected on individual nests or over small portions of a breeding season (e.g., Fletcher and Webby 1977, Fowles 1981, Cabot et al. 1988, Booms and Fuller 2003). Not until the early 1970s did investigations of Gyrfalcon ecology in Greenland begin in the Low Arctic, and even then, the Gyrfalcon was of secondary interest to the Peregrine Falcon (Falco peregrinus) (Burnham and Mattox 1984). Only during one four-year period (1990-93) did systematic surveys for nesting Gyrfalcons take place (central-west Greenland); however, results from these surveys were difficult to interpret (W. Mattox, unpubl. data, M. Yates unpubl. data). In High Arctic Greenland ( $70^{\circ}$ $\mathrm{N}$ or more, see Bliss 1979), summer information was restricted to notes made by early explorers, birding surveys/expeditions, or single seasons spent observing particular nests (e.g., Stone 1895, Cabot et al. 1988). In a review article about the Gyrfalcon, Cade et al. (1998) commented that "fresh data from
Greenland and Russia lag far behind" that from other locations.

To address this lack of knowledge, we collected long-term data from both Low and High Arctic breeding populations in central-west (Kangerlussuaq) and northwest (Thule) Greenland, respectively (Figure 1). We compared data between areas and considered historical data where available. We analyzed changes in breeding biology over time to look for potential shifts possibly associated with climate change.

\section{MethodS}

We studied populations of breeding Gyrfalcons in central-west (Kangerlussuaq, 66.5-67.5 ${ }^{\circ} \mathrm{N}$ ) Greenland from 1994-2006 and northwest (Thule, 75.9-77.6 N) Greenland from 19942005 and 2006-2010 (Figure 1). These locations are geographically separated by approximately $1,170 \mathrm{~km}$ with limited or no ice-free land existing between the two sites.

The Kangerlussuaq study area is considered Low Arctic and is located in one of the largest ice-free areas within Greenland. The area is bisected by numerous lakes, rivers, streams, and rolling valleys (Figure 2). Vegetation is primarily sedges and grasses, with willow (Salix) up to $2 \mathrm{~m}$ in height. Small passerines, for example, Lapland Longspurs (Calcarius lapponicus), Snow Buntings (Plectrophenax nivalis), Northern Wheatear (Oenanthe oenanthe), and others, occur in abundance, with Rock Ptarmigan (Lagopus muta), waterfowl, and shorebirds also present. For additional information on the Kangerlussuaq study area, see Burnham and Mattox (1984) and Burnham (2008).

Further north, the Thule study area is almost entirely coastal, with the largest ice-free margin extending approximately $26 \mathrm{~km}$ from the sea. The area is considered to be High Arctic, with sparse, prostrate vegetation. Cliffs are almost always sea-facing (Figure 2). The most numerous bird species in the Thule area is the 


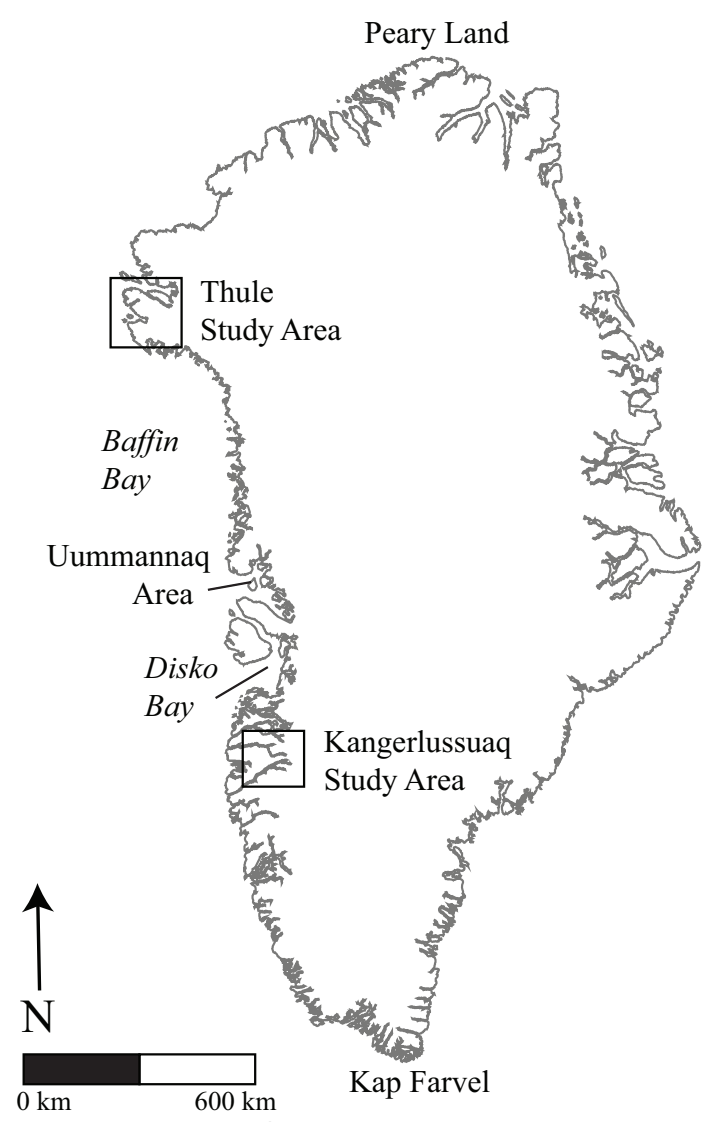

Figure 1. Map of Greenland showing study areas and locations mentioned in the text.

Dovekie (Alle alle), which has an estimated breeding population of 33 million pairs in the Thule area (Egevang et al. 2003). Additionally, Thick-billed Murres (Uria lomvia), Blacklegged Kittiwakes (Rissa tridactyla), and Black Guillemots (Cepphus grille) occur in large numbers, with lesser numbers of passerines and Rock Ptarmigan. For further information on the Thule study area, see Burnham (2008).

In the Kangerlussuaq area, most Gyrfalcon nest sites were previously located by Burnham and Mattox (1984), M. Yates (unpubl. data), and W. Mattox (unpubl. data), with most discovered incidentally while surveying for Peregrines. New nest sites were also located during this study while traveling between known nesting sites. In addition to an historic literature

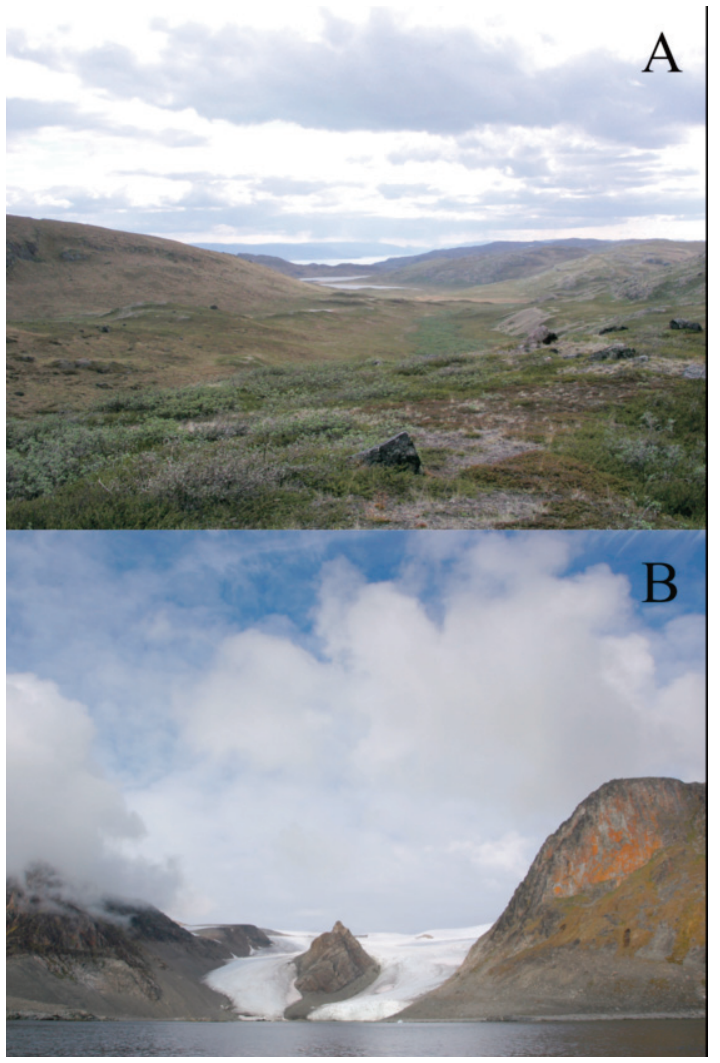

Figure 2. Photos of the Kangerlussuaq $(A)$ and Thule (B) study areas showing typical habitat.

search, individuals with first-hand knowledge of birds in Thule were contacted. Locations identified by local hunters and those found in the literature were first surveyed, with additional nesting locations found during systematic surveys of the coastline.

Occupied sites were those where one or more territorial adults and/or young were observed. To be considered successful, one or more chicks had to be observed. If only adults were present, they had to be seen on multiple visits to the site or to act territorially toward researchers to be considered as occupants. In the case of breeding, nests were rappelled or climbed into, prey remains were identified, and young were banded. Age of young was determined by counting backwards from the esti- 
mated average age of nestlings or fledglings. We assumed a four-egg clutch with an egg laid every other day, with incubation beginning on the third egg and a 35-day incubation period (C. Sandfort pers. comm., Platt 1977). Poole and Bromley (1988) reported that males fledged at 45-47 days and females at 47-50 days. We considered 47 days as an average fledging age.

While multiple nests on the same section of cliff (up to $0.5 \mathrm{~km}$ long) were considered to be the same nest site it is apparent that some Gyrfalcon nesting territories have alternate nest sites. Seven territories in Kangerlussuaq had multiple adjacent cliffs with nest sites (one to four) that were never used simultaneously during the entire study. This makes a strong case they were alternative nest sites within the same territories, although this cannot be proven with certainty as the adults were not banded. If true, the total number of known nesting territories available for breeding would be greatly reduced and nest sites could be grouped together by territory for analyses.

Depending upon weather conditions, we visited nests with breeding Gyrfalcons more than once per season to record the number of nestlings/fledglings. However, remote locations and inclement weather frequently precluded follow-up visits. We banded Gyrfalcons with a standard Danish numbered lock-on band on one leg and an alpha-numeric band (ACRAFT, Edmonton, Canada) on the other.

\section{Results}

Surveys and Occupancy. - Surveys for breeding Gyrfalcons took place from 1998-2006 in Kangerlussuaq and from 1993-2006 and 2008-2010 in Thule. Results from Kangerlussuaq and Thule surveys should be considered minimal estimates, with some nests likely failing before they were checked the first time, resulting in a bias towards successful nests. Surveys in Kangerlussuaq were primarily conducted by helicopter and occurred in early-to-
mid-June when young were usually around 20 days old. Surveys in Thule typically occurred from mid-to-late July through mid-August, when young were frequently at least 30 days old and in some cases had already left the nest. Surveys in Thule were usually conducted by boat, and due to the late break-up of ocean pack-ice, earlier surveys were not possible.

Surveys and Occupancy: Kangerlussuaq.From 1998-2006 $(\mathrm{n}=9), 51-96 \%$ (mean = $80 \%$ ) of known Gyrfalcon nesting locations were checked for occupancy in Kangerlussuaq (Table 1). During this period territorial Gyrfalcons were documented on 99 occasions and an additional 17 new nesting sites were located, giving a total of 74 known sites. The occupancy rate at previously known nest sites ranged from $10-27 \%$ (mean $=17 \%)$. When including new nest sites, a high of 15 sites were occupied in 1999 and 2000, and a low of five in 2003 (Table 1, Figure 3).

While it is possible that sites with single, nonbreeding pairs, or failed pairs of Gyrfalcons were missed, most locations where reproduction occurred were probably discovered. From 1998-2000, a limited number of nest sites surveyed by helicopter were also surveyed by other falcon researchers on foot during the same period. In total, 51 known Gyrfalcon nests were surveyed by both methods, with results between helicopter and foot surveys being the same.

Little information is available on the failure rate of Gyrfalcon nests in Kangerlussuaq during this study. However, in 1999 and 2000, surveys of known Gyrfalcon nest sites were conducted in the early spring (April, when egg laying occurred) in an attempt to determine the proportion later failing, with eight and six nests found occupied in the two years, respectively. Of those nests found occupied in the early spring, four were no longer occupied at a repeat survey in June 1999, and one was no longer occupied at a repeat survey in June 2000. Eggs were not observed at any of these nest sites in 
Table 1. Nest site occupancy by Gyrfalcons in Kangerlussuaq, Greenland, from 1998-2006.

\begin{tabular}{lclccc}
\hline Year & $\begin{array}{l}\text { Known } \\
\text { Gyrfalcon } \\
\text { nest sites }\end{array}$ & $\begin{array}{l}\text { Known } \\
\text { sites } \\
\text { checked (\%) }\end{array}$ & $\begin{array}{l}\text { Known sites } \\
\text { occupied when } \\
\text { checked (\%) }\end{array}$ & $\begin{array}{l}\text { Total sites } \\
\text { occupied (new } \\
\text { sites found) }\end{array}$ & $\begin{array}{l}\text { Total } \\
\text { successful } \\
\text { sites }\end{array}$ \\
\hline 1998 & 57 & $43(75 \%)$ & $7(16 \%)$ & $10(3)$ & 10 \\
1999 & 60 & $54(90 \%)$ & $11(20 \%)$ & $15(4)$ & 13 \\
2000 & 64 & $55(86 \%)$ & $10(16 \%)$ & $15(5)$ & 15 \\
2001 & 69 & $59(86 \%)$ & $11(19 \%)$ & $13(2)$ & 12 \\
2002 & 71 & $37(51 \%)$ & $10(27 \%)$ & $5(0)$ & 3 \\
2003 & 71 & $47(64 \%)$ & $5(11 \%)$ & $10(1)$ & 7 \\
2004 & 71 & $59(81 \%)$ & $9(15 \%)$ & $9(2)$ & 9 \\
2005 & 72 & $71(96 \%)$ & $7(10 \%)$ & $12(0)$ & 9 \\
\hline
\end{tabular}

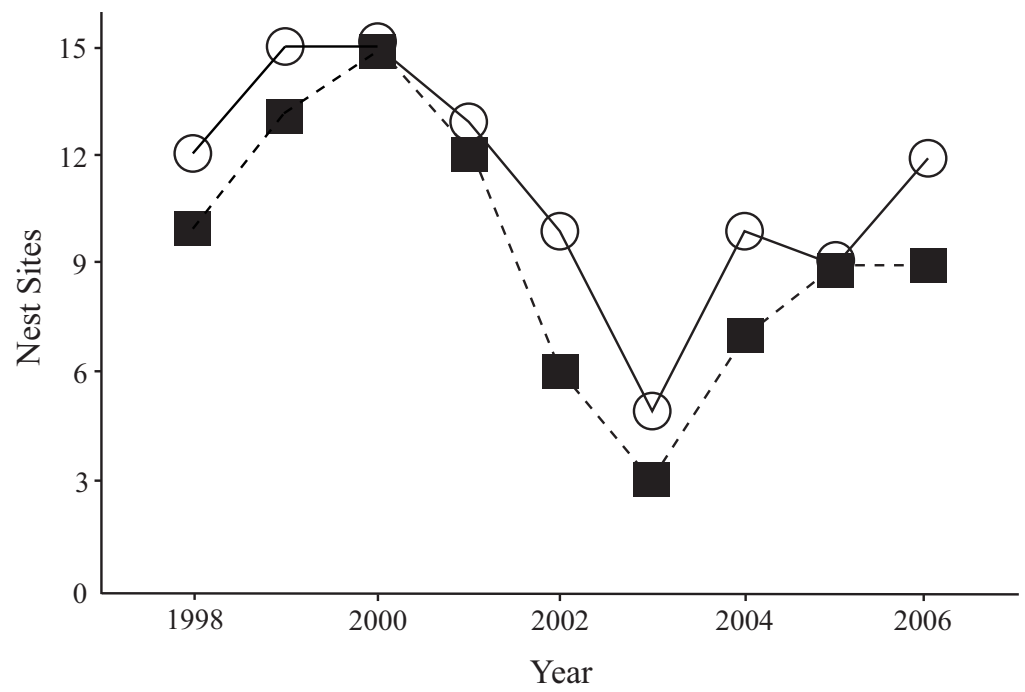

Figure 3. The number of occupied (open circles) and successful (filled squares) Gyrfalcon nest sites in Kangerlussuaq, Greenland, from 19982006.

the early spring and, although adults appeared to be incubating in some instances, pairs may have moved to other nests in the vicinity. In 1999 and 2000, four nest sites that were not occupied in April were found to be occupied by breeding pairs of Gyrfalcons when they were re-checked in June. This would be expected from the large range of egg laying dates observed in Kangerlussuaq ( $>40$ days in some years, see later section on nesting chronology). Based on these poor and inconclusive results, and safety concerns for falcons, early spring surveys were discontinued.
Surveys and Occupancy: Thule.-Surveys for breeding Gyrfalcons took place from 19932006 and 2008-2010 ( $\mathrm{n}=17$ years) in Thule, with territorial pairs of Gyrfalcons documented 77 times at 25 locations (Table 2). With the addition of a new research boat in 2001, our coastal survey area approximately tripled. From 2001 onward, our survey area remained relatively constant, with annual variation in nest sites checked for occupancy based on inclement weather and summer sea ice. 
Table 2. Nest site occupancy by Gyrfalcons in Thule, Greenland, from 1993-2006 and from 2008-2010.

\begin{tabular}{|c|c|c|c|c|c|}
\hline Year & $\begin{array}{l}\text { Known } \\
\text { Gyrfalcon } \\
\text { nest sites }\end{array}$ & $\begin{array}{l}\text { Known sites } \\
\text { checked } \\
(\%)\end{array}$ & $\begin{array}{l}\text { Known sites } \\
\text { occupied when } \\
\text { checked (\%) }\end{array}$ & $\begin{array}{l}\text { Sites observed } \\
\text { occupied (new } \\
\text { sites found) }\end{array}$ & $\begin{array}{l}\text { Observed } \\
\text { successful } \\
\text { sites }\end{array}$ \\
\hline 1993 & - & - & - & - & 0 \\
\hline 1994 & - & - & - & (1) & 1 \\
\hline 1995 & 1 & $1(100 \%)$ & $1(100 \%)$ & $2(1)$ & 2 \\
\hline 1996 & 2 & $1(50 \%)$ & $1(100 \%)$ & $1(0)$ & 0 \\
\hline 1997 & 2 & 2 (100\%) & $2(100 \%)$ & $2(0)$ & 2 \\
\hline 1998 & 2 & $2(100 \%)$ & $2(100 \%)$ & $2(0)$ & 1 \\
\hline 1999 & 2 & $2(100 \%)$ & $1(50 \%)$ & $3(2)$ & 2 \\
\hline 2000 & 4 & $3(75 \%)$ & $3(100 \%)$ & $3(0)$ & 2 \\
\hline 2001 & 4 & $4(100 \%)$ & $1(25 \%)$ & $4(3)$ & 4 \\
\hline 2002 & 7 & $7(100 \%)$ & $6(86 \%)$ & $8(2)$ & 8 \\
\hline 2003 & 9 & $4(44 \%)$ & $1(25 \%)$ & $2(1)$ & 2 \\
\hline 2004 & 10 & $10(100 \%)$ & $7(70 \%)$ & $9(2)$ & 9 \\
\hline 2005 & 12 & $12(100 \%)$ & $6(50 \%)$ & $11(5)$ & 8 \\
\hline 2006 & 17 & $16(94 \%)$ & $5(31 \%)$ & $5(1)$ & 5 \\
\hline 2008 & 18 & 16 (89\%) & $6(38 \%)$ & $8(2)$ & 7 \\
\hline 2009 & 20 & $16(80 \%)$ & $5(31 \%)$ & $7(2)$ & 7 \\
\hline 2010 & 22 & $14(64 \%)$ & $5(36 \%)$ & $8(3)$ & 8 \\
\hline
\end{tabular}

During surveys for nesting Gyrfalcons in Thule, few if any occupied nests were likely to have been missed. Adults and juveniles were almost exclusively bright white in plumage and in general were obvious to the unaided eye when observed on cliffs, even at long distances. From 1993 to 2003, no obvious use of alternative nest sites occurred, and all breeding took place on ledges or in potholes. Beginning in 2004 and continuing to 2010 , it appeared likely that pairs began using alternate nesting sites within breeding territories; however, adults were not ringed and it was not possible to determine the specific movements of individuals. During this period, the use of Northern Raven (Corvus corax) nests by Gyrfalcons in the Thule area was observed for the first time, with multiple raven nests used in most years after 2004. The increase of new nesting sites after 2004 was primarily a result of these raven nests being used for nesting by Gyrfalcons, and in almost all instances, previously used ledges or potholes were within several kilometers.

Results from the Thule area provide the first data on the local Gyrfalcon population, but despite 17 years of research, only limited conclusions can be drawn on occupancy. Not until 2001 did surveys begin on a large enough scale to provide data on a number of nests each year. It appears that the Thule population was relatively stable, apart from 2003 and 2006, when only two and five occupied sites were found, respectively. The indicated low number of occupied nests in 2003 resulted from fewer previously known nest sites surveyed (see Table 2), and it does not appear that the population was peaking or crashing at any point during this study. 
Table 3. Nesting chronology of Gyrfalcons in the Kangerlussuaq (1998-2006) and Thule (1994-2010) study areas, Greenland. Hatch-dates were calculated from estimated age of young observed in the nest (see text), with data included from 66 nests in Kangerlussuaq and 40 in Thule.

\begin{tabular}{lll}
\hline & Kangerlussuaq mean (min-max, median) & Thule mean (min-max, median) \\
\hline Lay-date & 17 Apr (28 Mar-9 May, 18 Apr) & 5 May (24 Apr-24 May, 4 May) \\
Hatch-date & 26 May (6 May-17 Jun, 27 May) & 13 Jun (2 Jun-2 Jul, 12 Jun) \\
Fledge-date & 12 Jul (22 Jun-3 Aug, 13 Jul) & 30 Jul (19 Jul-18 Aug, 29 Jul) \\
\hline
\end{tabular}

Occupancy of nest sites is difficult to compare between Kangerlussuaq and Thule. Within the Kangerlussuaq area, the majority of Gyrfalcon nest sites were documented by others prior to this study, which provided us with significant overall knowledge of the study area. In Thule, we had no previous knowledge of nest site locations, and each year required new and extended surveys.

Reproduction: Kangerlussuaq.-During 19982006 , a minimum of 236 young were produced at the 99 occupied Gyrfalcon nest sites located in Kangerlussuaq (2.38 young per occupied site). At successful sites $(n=84)$, where at least one chick was observed, an average of 2.81 young were produced, with the number of young per nest ranging between one and five.

The numbers presented here are minima as it was frequently impossible to ascertain the total number of young. In some cases, chicks were too young, too near fledging, or cliffs were too overhung for the nest to be entered safely. When young were small, less than one week old, adult females frequently did not leave the nest when approached by helicopter. Observations were thus limited to a mass of nestling down under the front of the female's breast, or in some cases, nothing was visible under the female, in which case, we noted the female as incubating/brooding but did not count the nest as successful. To some extent, this explains the difference between occupied $(n=99)$ and successful $(n=84)$ nests, with some nests having not actually failed, but reproduction being unknown. Given the wide range of nesting dates (some years up to 42 days between nests,
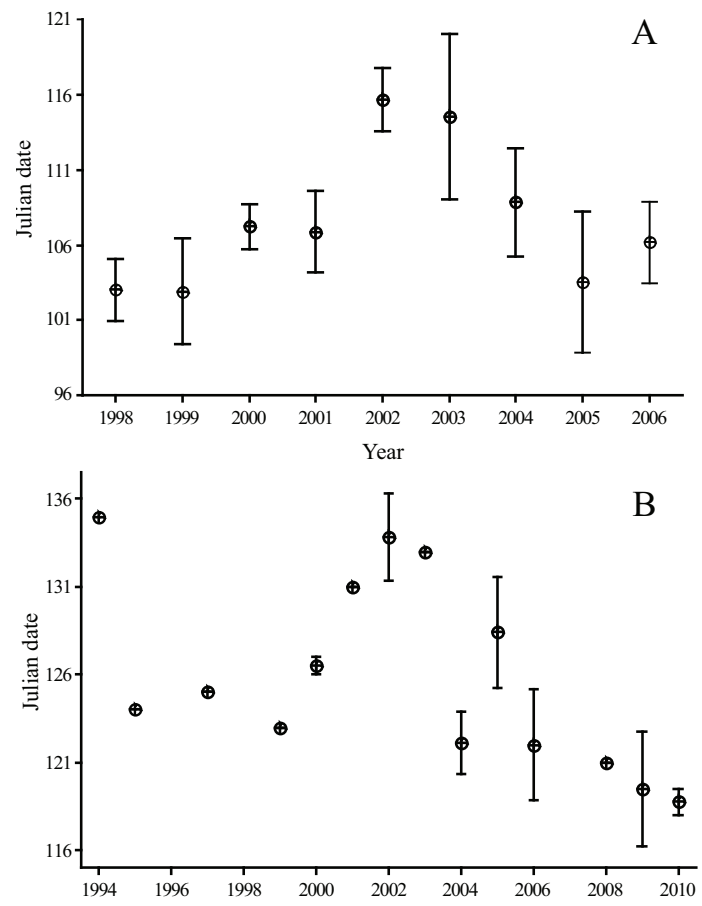

Figure 4. The mean $( \pm S E)$ of hatching dates recorded in Kangerlussuaq (A) from 1998 to 2006 and in Thule (B) from 1994-2006 and 2007-2010. No data available from Thule for 1996, 1998, and 2007. 
see section below on nesting chronology), these numbers should be viewed with caution, as a sizeable portion of chicks were very young when their age was noted and some proportion likely did not survive to fledging. Numbers given here for productivity should not be interpreted as numbers of chicks fledged.

Reproduction: Thule.-Using the same criteria we used for sites being occupied and successful in the Kangerlussuaq area, we located 77 occupied territories in Thule that produced over 179 chicks, for an average of at least 2.38 young per occupied nest. At the 69 successful sites, an average of 2.63 young were produced. The number of young produced at individual nests ranged from one to five, with young over half-grown at all but one of the successful nest sites when first visited. Young in Thule were rarely banded, with young being too near fledging to safely enter the nest, or already flying in many cases. No females were observed incubating during surveys in Thule.

Nesting Chronology.-Gyrfalcons in Kangerlussuaq began nesting approximately 18 days earlier than those in Thule, with the first egg laid on 17 April $(\mathrm{SD} \pm 9.3)$ and 5 May $(\mathrm{SD} \pm$ 7.0), respectively (Table 3, Figure 4). Calculating forward, young departed the nest around 12 July in Kangerlussuaq and 30 July in Thule (Table 3). We were unable to determine the age of young at 22 nests in Thule as they had already fledged. The majority of these nests (77\%) were surveyed from early August onward (after the mean fledging date), but data from these nests would have likely had little impact on calculated nesting chronology. Based on research in Canada and Iceland (Cramp and Simmons 1980, Nielsen and Cade 1990, respectively), showing that young Gyrfalcons become independent of adult care at an average of $\geq 4$ weeks after they left the nest, independence would be reached in mid-August in Kangerlussuaq and early September in Thule.

In Kangerlussuaq, a significant relationship ( $\mathrm{P}$ $\left.<0.05, \mathrm{r}^{2}=0.48\right)$ existed between the number of successful nests found each year and the average date that breeding was initiated; fewer pairs of Gyrfalcons produced young in years of late breeding (Figure 5). No significance was found between the total number of occupied nests and timing of breeding $\left(\mathrm{P}>0.05, \mathrm{r}^{2}=\right.$ 0.27). In Thule, from 1994-2010 (no data for 1996, 1998, and 2007), the average lay-date for the Gyrfalcon population significantly advanced $\left(P<0.05, r^{2}=0.32\right.$, Figure 6$)$, with the average lay-date for the final year of the study being six days earlier than for the entire 17 -year study period as a whole (29 April vs. 5 May).

In general, Gyrfalcons in Kangerlussuaq showed a much wider range of dates during which reproduction occurred. In Kangerlussuaq, fledging dates spanned a 43-day period (22 June-3 August) compared to a 31-day period in the more northern Thule area (19 July-18 August) (Table 3). In one instance in Kangerlussuaq, two nests were visited on the same day (within $20 \mathrm{~km}$ of each other), with one nest containing pipped/hatching eggs and the other nest having young that were almost fully feathered and ready to depart the nest (approximate 42-day difference).

Prey.-Jenkins (1978), Burnham and Mattox (1984), and Booms and Fuller (2003) have documented prey species delivered to Gyrfalcon nest sites in Kangerlussuaq. It was determined that Gyrfalcons prey on virtually all small- to medium-size birds and mammals in the area. During this study, ptarmigan remains were the most common prey item in Gyrfalcon nests, e.g., one 2005 nest, with four, approximately 38-day-old nestling Gyrfalcons, contained 55 ptarmigan and 2 Long-tailed Duck (Clangula hyemalis) sterna. Arctic Hare (Lepus arcticus), Snow Bunting, and Lapland Longspur remains were also found, but in much less frequency than ptarmigan remains. Burnham and Mattox (1984) emphasized the apparent importance of passerines (from 1972 to 1981) as food to supplement ptarmigan and hare when their numbers were few. 

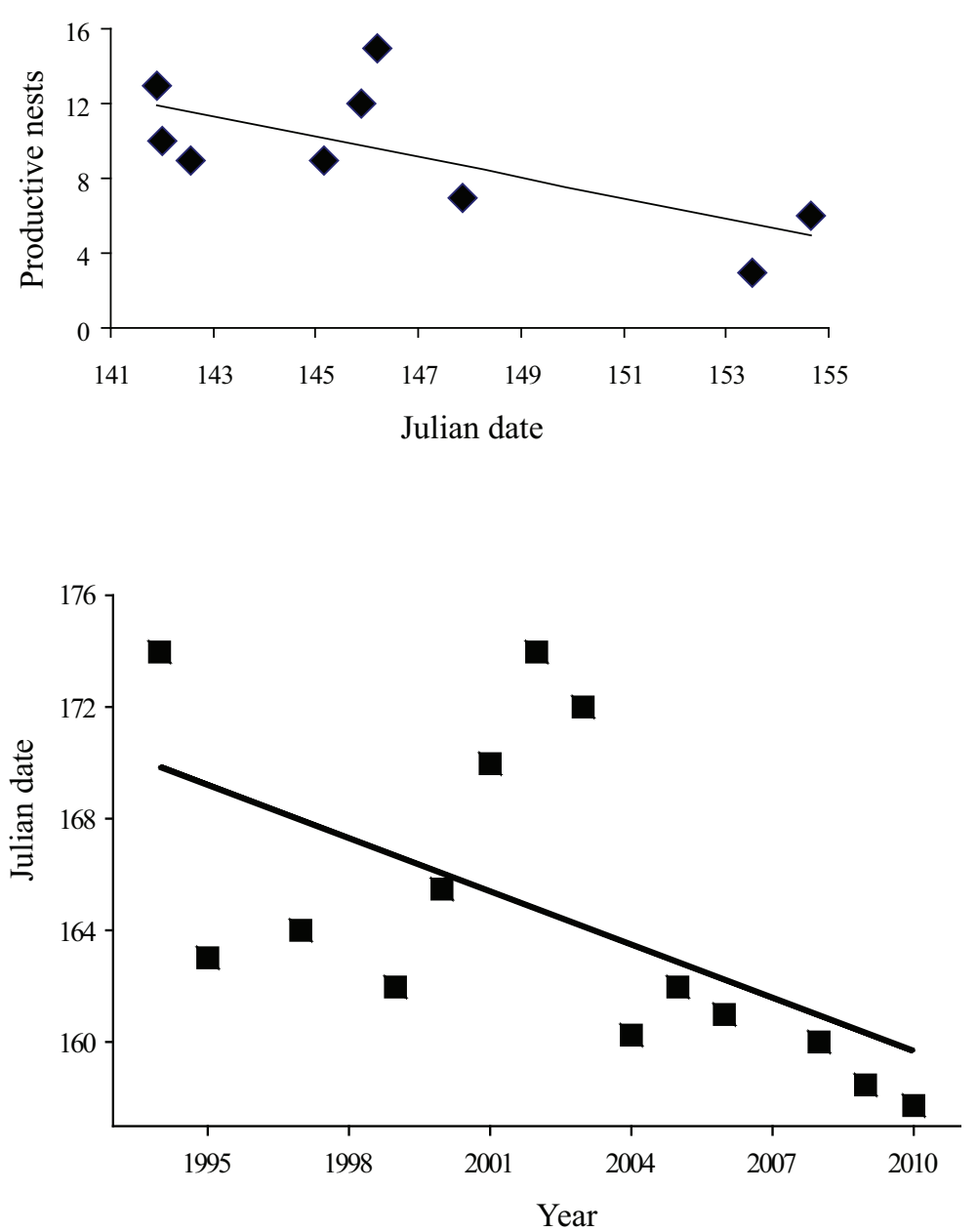

Figure 5. Significant relationship $\left(P>0.05, r^{2}=\right.$ 0.48 ) between the average date of breeding (Julian hatch-date shown here) and the number of successful nests. This suggests that latebreeding Gyrfalcons produce fewer broods and that overall production is lower in years when the population as a whole nests later.

Figure 6. Negative trend over time showing that the average date breeding was initiated in Thule significantly $\left(P<0.05, r^{2}\right.$ $=0.32$ ) advanced (became earlier) during the 17-year study period. Julian hatchdate shown here.
In Thule, prey remains were collected at 40 Gyrfalcon nest sites during the 17-year study. Dovekie remains were present in $75 \%$ of the nests. Fourteen nests had exclusively Dovekie remains, the only prey species for which that was the case. Rock Ptarmigan remains were found at 12 nests (30\%), Black Guillemot at 10 $(25 \%)$, Arctic Hares at $6(15 \%)$, Long-tailed Ducks at $5(13 \%)$, Black-legged Kittiwakes at $3(8 \%)$, passerines at $2(5 \%)$, and Common Eiders (Somateria mollissima), Snow Geese (Chen caerulescens), and Thick-billed Murres at $1(3 \%)$. Although prey transects were not conducted, there was an obvious positive correlation between potential prey seen in the areas of nest sites and prey species remains in nests. For example, one nest site located approximately $60 \mathrm{~km}$ up a long fjord and further from any breeding seabird colony yielded mainly Arctic Hare leverets, Rock Ptarmigan, and passerine remains.

Plumage Color Variants._During 1998-2006 in Kangerlussuaq, the plumage color of 137 adults was recorded as 71 (52\%) "white," 16 (12\%) "silver," and 50 (36\%) "grey." Observations of adult females at nests were more frequent (80 vs. 57) than males, as might be expected (Table 4). The ratio of white and grey females was nearly even ( $43 \%$ vs. $41 \%)$, but $65 \%$ of adult males were white compared to only $30 \%$ grey. 
Table 4. Plumage color of adult Gyrfalcons observed in Kangerlussuaq from 1998-2006.

\begin{tabular}{llrl}
\hline & Adult females & \multicolumn{2}{c}{ Adult males } \\
\hline White & $34(43 \%)$ & 37 & $(65 \%)$ \\
Silver & $13(16 \%)$ & 3 & $(5 \%)$ \\
Grey & $33(41 \%)$ & 17 & $(30 \%)$ \\
Total & 80 & 57 & \\
\hline
\end{tabular}

More than 285 juvenile and adult Gyrfalcons were observed during 1993-2010 in Thule, of which only two had grey plumage (an adult female and her daughter), and one silver. The remainder of the Gyrfalcons had very white plumages and many showed no visible dark pigmentation on their tails, even as juveniles. Repeat sightings may have occurred from one year to the next in both study areas as few adults were ringed and it was not possible to tell individuals apart. Color phases of individuals were expected to remain consistent throughout their lives, as evident from captive birds.

\section{Discussion}

The world population of Gyrfalcons was estimated by Cade $(1960,1982)$ at $15,000-17,000$ pairs. More recently Potapov and Sale (2005) estimated the world population at 7,88010,900 pairs by totaling country estimates. For Greenland alone, Mattox (1970) estimated 850 pairs, Cade (1982) 500-1,000 pairs, and most recently Boertmann (2008) estimated the population to be no more than 500 pairs. Based on these estimates, Greenland contains a possible $5-10 \%$ of the world Gyrfalcon population.

One of the most important influences on the breeding density of birds is food supply (Lack 1954, 1966, Newton 1979, 1998). Ratcliffe (1969) showed that for three inland Peregrine Falcon populations in the United Kingdom the average breeding home range per pair for each area was correlated with primary-productivity and food. Numerous other raptor species have shown significant relationships between prey abundance and nesting density (see Newton 1979).

Rock Ptarmigan have been shown to have cyclic population fluctuations throughout the Arctic (Gudmundsson 1960, Weeden and Theberge 1972, Watson et al. 1998, Moss and Watson 2001), and specifically in Greenland (Salomonsen 1950). Based on hunter kills, Vibe (1967) found ptarmigan populations to fluctuate in Greenland on approximately 11year cycles from 1886 to 1954 . Nielsen (1999) reported a 10-year cycle for ptarmigan in Iceland and found that Gyrfalcon populations lagged behind by 3 years. Mossop and Hays $(1982,1994)$ reported that, in the Yukon Territory, the Gyrfalcon breeding population fluctuated on a 10-year cycle, probably following population fluctuations of Willow Grouse (Lagopus lagopus). Additionally, Nyström et al. (2005) showed a significant relationship between the number of Gyrfalcon chicks fledged each year and ptarmigan population levels. Alternatively, Mindell et al. (1987) and Mindell and White (1988) found no relationship between Gyrfalcon and ptarmigan populations in Alaska, and Shank and Poole (1994) found the same for Canada's Northwest Territories (but see Mossop 2011, Barichello and Mossop 2011).

In Kangerlussuaq, where ptarmigan remains were found most frequently in Gyrfalcon nests from 1998-2006, it is difficult to know whether a response relationship between Gyrfalcons and ptarmigan exist. However, based on our data, it appears a peak in occupied Gyrfalcon nest sites occurred in 1999 and 2000, followed by a steady decline and then increase (Figure 3). This pattern would be expected if indeed the Gyrfalcon population was fluctuating with a cyclic ptarmigan population. Unfortunately, no recent information is available on the annual fluctuations of the ptarmigan population in Greenland, with historic data based on casual observations, local inhabitants, and hunter kills (Salomonsen 1950, Vibe 1967). 
Prey differences between Kangerlussuaq and Thule were apparent primarily in the large numbers of songbirds in Kangerlussuaq from mid-May to mid-September, and in the tens of millions of seabirds present in northwest Greenland from mid-May to August-September. In general, Gyrfalcons appeared to prey upon all suitable species present locally in their breeding areas.

In both Kangerlussuaq and Thule, it seems probable that Gyrfalcon numbers, or nesting density, were regulated to prey, and specifically ptarmigan. Of primary importance is the prey availability when the Gyrfalcons first arrive on territory in spring; Rock Ptarmigan, Snow Buntings, and adult Arctic Hares are present in Kangerlussuaq, and Rock Ptarmigan and adult Arctic Hares in Thule. It is likely that Rock Ptarmigan are the single most important prey species early in the season, as shown by Nielsen and Cade (1990) in Iceland, and are thus essential to Gyrfalcon breeding in Greenland.

Population Changes.-Although there are insufficient data to state accurately whether a population change in Gyrfalcons has occurred in Greenland, some regional decreases may have occurred, particularly from the Uummannaq District south to the southwestern tip of Greenland. For this region, comparing the number of Gyrfalcons reported by Bertelsen (1921) in the early 1900s with that of Burnham et al. (2005) in 2000, almost 100 years later, fewer pairs were located during the later survey. Additionally, in the Disko Bay area, no breeding Gyrfalcons were located by Burnham and Sherrod in 1974 (Burnham and Mattox 1984), despite Salomonsen's (1950) statement that the Gyrfalcon breeds "rather locally in S.W. Greenland but in the Disko Bay region it increases considerably in number," referencing Bertelsen (1932) and Fencker (1929).

Only four years of previous surveys were done in the Kangerlussuaq area specific to Gyrfalcons, from 1990 to 1993 (M. Yates unpubl. data, W. Mattox unpubl. data). During this period, Gyrfalcons were observed at 13, 22, 7, and 6 nest sites, respectively, and all these sites were included in our study. However, between the earlier study period and our study period, the overall size of the study area increased, with a new and very productive valley to the north of the original study area included in the surveys from 1998 onward. The data from the original study area in both periods are given in Table 5. Data in the "initial study area" encompassed all nest sites known from 1990 to 1993, in addition to other nest sites found later, but within the same area/boundaries.

Only from 1990-1993 and from 1998-2006, when surveys were conducted specifically for Gyrfalcons, were occupancy records comparable. Using occupied and successful nest sites located within the initial study area (Table 5), there appeared to be two possible Gyrfalcon population peaks: in 1991 and 1999-2001. The high in 1991 was followed by a large and immediate drop, while the high from 1999 to 2001 was followed by a similar rapid drop. The time interval between population peaks and lows appeared to be 8 and 10 years, respectively, and followed a cyclical pattern similar to that as described by Nielsen (1999) and Mossop and Hays $(1982,1994)$ for Gyrfalcon populations heavily dependent upon ptarmigan. Although the initial peak and decline from 1991-1993 was slightly more severe than for the period 1999-2003, this may simply be a function of peak height and trough depth varying from one cycle to another, as has been observed in other species which fluctuate cyclically.

Despite a doubling in the number of nest sites known and surveyed, and improved survey techniques (foot, small planes, and some helicopters in the early 1990s versus primarily small helicopter during this study), the number of occupied nests has decreased in the Kangerlussuaq area from the earlier to latter study period (Table 5, Figure 7).

Interactions Between Gyrfalcons and Peregrines.-The Peregrine Falcon population in 
Table 5. Nest site occupancy by Gyrfalcons in Kangerlussuaq, Greenland, from 1990 to 1993 and from 1998 to 2006 in the "initial study area." (M. Yates unpubl. data for 1990-1993, Mattox unpubl. data for 1990-1993).

\begin{tabular}{lcccc}
\hline Year & $\begin{array}{l}\text { Occupied (\% of } \\
\text { checked occupied) }\end{array}$ & Successful & $\begin{array}{l}\text { Known Gyr sites } \\
\text { checked (\%) }\end{array}$ & $\begin{array}{l}\text { Known } \\
\text { Gyrfalcon sites }\end{array}$ \\
\hline 1990 & $13(52 \%)$ & 7 & $25(100 \%)$ & 25 \\
1991 & $22(69 \%)$ & 12 & $32(100 \%)$ & 32 \\
1992 & $7(18 \%)$ & 3 & $38(100 \%)$ & 38 \\
1993 & $6(15 \%)$ & 0 & $40(100 \%)$ & 40 \\
\hline 1998 & $8(18 \%)$ & 8 & $45(78 \%)$ & 58 \\
1999 & $11(20 \%)$ & 10 & $54(92 \%)$ & 59 \\
2000 & $11(20 \%)$ & 11 & $55(90 \%)$ & 61 \\
2001 & $11(20 \%)$ & 10 & $55(90 \%)$ & 62 \\
2002 & $8(25 \%)$ & 4 & $32(52 \%)$ & 62 \\
2003 & $5(12 \%)$ & 2 & $42(68 \%)$ & 62 \\
2004 & $7(13 \%)$ & 6 & $53(85 \%)$ & 62 \\
2005 & $6(10 \%)$ & 6 & $60(97 \%)$ & 62 \\
2006 & $8(14 \%)$ & 7 & $58(94 \%)$ & 62 \\
\hline
\end{tabular}

Figure 7.

Changes in the number of surveyed (filled boxes), occupied (open circles), and successful (open triangles)

Gyrfalcon nests in Kangerlussuaq from 1990-1993 and 1998-2006.

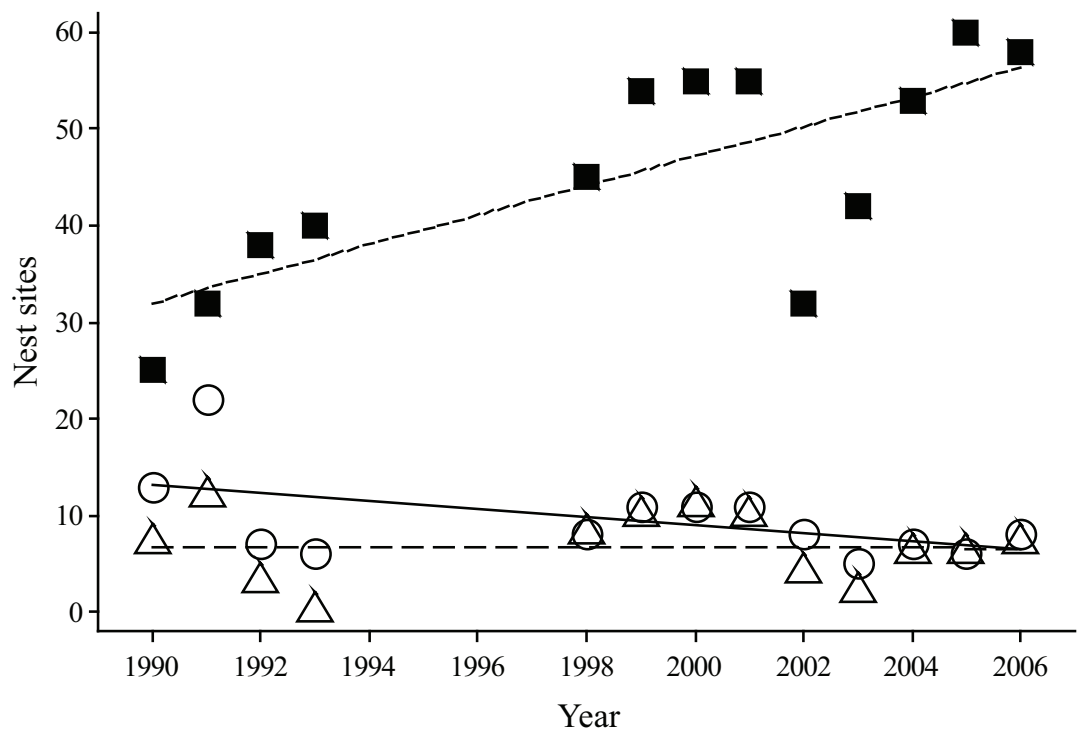


the Kangerlussuaq area has dramatically increased over time, from 34 known nest sites found from 1972 to 1981 (Burnham and Mattox 1984) to over 170 known nests sites in 2006 (Burnham 2008). There is little doubt that, at the same time the ratio of nesting Peregrines to Gyrfalcons has also changed from a reported ratio of nearly 1:1 during 1972-1981 (Burnham and Mattox 1984) to between 4 and $8: 1$ by the early 1990 s (calculated using Mattox 1998). Using information on occupancy collected by Mattox (1998) during 1988-1997, the last 10 years of large scale surveys for Peregrines made in the Kangerlussuaq area, an average of $84.7 \%$ (median $=85, \mathrm{SD} \pm 6.7$ ) of checked sites were occupied. If occupancy remained similar during this study, then approximately 144 Peregrine nests were likely occupied each season, making the ratio of Peregrines to Gyrfalcons in the Kangerlussuaq area between 10 and 29:1, depending upon the number of occupied Gyrfalcon nests each year.

Although perhaps ultimately driven by climate change, might the probable Gyrfalcon population decline be associated with the increase in Peregrines? Salomonsen (1950) states, "The number of Gyr-Falcons in the low-arctic region is probably to some extent checked by the Peregrine..." He made the statement because of overlap between the species in food and nest sites. In Kangerlussuaq, territorial Peregrines and Gyrfalcons were observed nesting on the same cliff $\geq 25$ times from 19832006 (W. Mattox unpubl. data and this study). During 1972-1982, Burnham and Mattox (1984) never observed the two species nesting on the same cliff. At a cliff where a pair of Gyrfalcons and Peregrines nested simultaneously in 2001, the adult female Gyrfalcon was found below the cliff unable to fly, evidently because of concussion. After being held in captivity for a short time she was released at the nest site, but disappeared within days, her small young dying shortly after. The Peregrines were very aggressive, and successfully reared their own young. Aerial encounters between the species were seen several times, and we were never convinced that Gyrfalcons were dominant over Peregrines. Rather, on several occasions, Peregrines were observed driving adult Gyrfalcons away from nests and/or fledged young, on occasion even striking the Gyrfalcon and locking feet. Similar observations were made by Fowles (1981) who commented that "The large falcon tended to look clumsy and confused as it attempted to evade the agile stoops of the...Peregrines." The Peregrine is typically very aggressive toward other species, including other Peregrines (Tordoff and Redig 1997).

Other than by direct aggression and displacement, how might Peregrines influence breeding Gyrfalcons? Direct displacement is probably difficult for Peregrines because the Gyrfalcons begin breeding earlier in the spring. But indirect displacement may occur through the Peregrine's influence on the ptarmigan population. As shown by Rosenfield et al. (1995), fledgling Rock Ptarmigan can make up a significant portion of the diet at Peregrine nests in Kangerlussuaq. When Gyrfalcons arrive at nest sites, and throughout much of their incubation, the prey species available are primarily ptarmigan, adult hare, and Snow Buntings. Of the three, ptarmigan is probably the most important. As Peregrine numbers have increased in Kangerlussuaq, so has their probable impact on ptarmigan, reducing the number surviving the summer and autumn seasons, and reducing the number of birds available in the spring.

A similar situation with Peregrines and Hen Harriers (Circus cyaneus) holding Red Grouse (Lagopus l. scoticus) populations at low levels has been described in Scotland (Redpath and Thirgood 1999). Again, both raptors were supported at high density mainly by other prey, but had their major impact on the more vulnerable grouse. Neither raptor in Scotland was as heavily dependent on grouse as Greenland Gyrfalcons were on ptarmigan. Likewise, in Norway, Selås (1998) studied the effect of Red Fox (Vulpes vulpes) density on Goshawks 
(Accipter gentilis). Through a natural experiment where Goshawk, fox, and grouse populations were monitored over several decades in a $650-\mathrm{km}^{2}$ area, it was determined that Red Fox influenced Goshawk breeding densities negatively by limiting the number of grouse. We suggest that this type of relationship is occurring between Peregrine, Gyrfalcon, and ptarmigan populations in Kangerlussuaq.

Reproduction.- Reproduction may have varied regionally and annually, but we do not have enough information to show this in Greenland. As mentioned in the results, in both the Kangerlussuaq and Thule areas, it was frequently difficult to determine the total number of young at Gyrfalcon nest sites. Therefore, most numbers provided are minima. Additionally, the difference in reproduction between occupied and successful nests was likely underreported, because surveys took place late in the breeding season; at nest sites that had failed, adults may have already left the area, biasing the results towards successful nests. Further, although Gyrfalcon reproduction has been shown elsewhere to fluctuate between years in response to prey densities (White and Cade 1971, Nyström et al. 2005), it was not possible to determine if this was the case in Greenland.

Potapov and Sale (2005) reported a mean brood size of 2.6 young $(\mathrm{SD} \pm 0.91, \mathrm{n}=364$ ) across the entire range of the Gyrfalcon. In Kangerlussuaq, Burnham and Mattox (1984) reported an average of 2.6 young per successful nest $(n=20)$ from $1972-1981$ for nests they could observe. During this study, slightly more young per successful nest were produced in Kangerlussuaq (2.81) compared to data from Burnham and Mattox (1984), while an almost identical number of young per successful nest were found in Thule (2.63). Chicks in Thule appeared to be 2-3 weeks older on average when surveys occurred, with many sites in Thule having young near to fledging or already fledged. Accordingly, the observed difference in nest success would likely have been more similar had surveys occurred when young were approximately the same age in both areas. On several occasions in Kangerlussuaq, we found the remains of dead young from the previous year, in some cases fully feathered, below the nest site.

Breeding Chronology. - As expected, the more northern Thule population bred seasonally later than the Kangerlussuaq population to the south, with similar differences observed between Peregrine populations in both areas (Burnham 2008, Burnham et al. in press). Greater nesting synchrony was also observed in the starting dates for Gyrfalcons breeding in the north versus south, as described for other raptors by Newton (1979).

For Kangerlussuaq, fewer successful nests were found in years when breeding was initiated later in the season (Figure 5). Similar trends have been observed in numerous other raptor species, including Sparrowhawks (Accipiter nisus), Peregrines, and Bald Eagles (Haliaeetus leucocephalus) (Newton and Marquiss 1984, Herbert and Herbert 1965, Broley 1947 , respectively). Why the Gyrfalcon population in Kangerlussuaq bred later in some years is unknown. The availability of prey and inclement weather have been shown to be the most common causes of variation in nesting in most birds (Lack 1954, 1966, Newton 1979, 1998), but without more information on either of these variables, particularly ptarmigan density, no conclusions can be drawn.

During this study, the lay-date of Gyrfalcons in Thule significantly advanced (Figure 6). Advancement of lay-date has also been observed in numerous other species of birds (e.g., Crick et al. 1997, Crick and Sparks 1999, Dunn and Winkler 1999, Both et al. 2004) and is considered to be one of the most likely effects of climate change on bird species over time (IPCC 2007). From north Greenland, including the Thule area, temperatures have been increasing since the late 1900s (Whitfield et al. 2004). In particular, Mountain et al. (2001) and Serreze et al. (2000) found spring 
temperatures to be increasing throughout this area, allowing for a milder and earlier spring. Already this change in temperature has been accompanied by an increasing Peregrine population in the Thule area (Burnham 2008, Burnham et al. in press) and is likely also enabling Gyrfalcons to begin nesting earlier.

Plumage Color Variants.-The observed plumage color variation in Kangerlussuaq and Thule is comparable with findings reported elsewhere for Gyrfalcons, with a higher proportion of white falcons in the north. Slightly to the south of the Kangerlussuaq area, Salomonsen (1950) reported a 50:50 ratio of white and darkplumage Gyrfalcons. In Kangerlussuaq during 1972-1977, the plumage of 29 adult Gyrfalcons was recorded as 16 (55\%) white and 13 $(45 \%)$ grey (W. Burnham unpubl. data). During 1998-2006, we documented plumage color of 137 adults as $71(52 \%)$ white, $16(12 \%)$ silver and $50(36 \%)$ grey. During the 1970s, silver was included with grey, and if we lump silver and grey Gyrfalcons together our ratio is nearly identical. Based on these results it appears no shift in plumage color has occurred in the past 50-60 years.

The observed difference in plumage color between breeding females and males in Kangerlussuaq was unexpected, with $43 \%$ of females and $65 \%$ of males being white. To our knowledge this is the first instance in Gyrfalcons where such a large difference was observed between sexes within the same area. More research is needed to determine why this is occurring.

\section{Conclusion}

These are the first long-term studies ever conducted on Gyrfalcon populations within Greenland. Based on information collected by others and data from this study it appears that the population in Kangerlussuaq is at best stable, and may be slowly declining. Population peaks were observed in both 1991 and in 1999 and 2000 in Kangerlussuaq, with approximately one-third fewer occupied sites found during the latter period and $69 \%$ of surveyed sites occupied vs. $20 \%$ and $16 \%$, respectively, with similar numbers of successful sites observed between periods. However, more previously-used nest sites were known and surveyed during the latter period, with more thorough and improved surveys not finding more nesting falcons. The population in Thule appears to be stable, with only minor fluctuations occurring during this study, but with breeding pairs increasingly moving throughout the study area and using alternate nest sites.

The Gyrfalcon population in Kangerlussuaq began nesting approximately 18 days earlier than the population in Thule. No large differences were observed in reproduction, with the Kangerlussuaq sample producing slightly more young per successful nest but equal numbers of young per occupied nest. In years when breeding began later in Kangerlussuaq, fewer successful nests were found. The initiation of breeding advanced in Thule during our study period, likely in association with earlier and warmer springs.

It is difficult to determine with certainty what effect climate change is having on Gyrfalcons, although it is clear that it is the driving force behind large-scale ecosystem change. Current observed climate change and future predictions suggest that Peregrine densities in Greenland will continue to increase, while at the same time their range will continue to move north into areas previously occupied only by Gyrfalcons. In contrast, Gyrfalcons, adapted to live in the cold Arctic conditions, may well retreat from many areas where they now occur. Continued research is needed to determine what effects, if any, both a warming climate and an expanding Peregrine population will have on Gyrfalcons in Greenland and throughout the Arctic.

\section{ACKNOWLEDGMENTS}

We thank I. Newton and J. Burnham for comments and suggestions. Additional thanks to the Greenland Home Rule Government for providing permits for this research. Logistical 
support was provided by Polar Field Services, the United States Air Force, Kangerlussuaq International Science Support, VECO (now CH2M HILL), $109^{\text {th }}$ Air National Guard, and the US Department of the Interior Bureau of Land Management. For many years of critical help collecting data in Greenland we give our thanks to B. and R. Mutch, J. Stephens, J. Cafferty, C. Offield, J. Johnson, and B. Konkel. Thanks also go to R. Abbott, E. Vaughn, E. Stockard, S. Zager, B. Vængtoft, B. Brodersen, K. Derry, and all the residents of both Thule Air Base and Kangerlussuaq for their friendship and assistance. Financial support was provided by The Peregrine Fund, Calen Offield and the Offield Family Foundation, Ruth O. Mutch, the Wolf Creek Charitable Foundation, Peter Pfendler, Comer Science and Education Foundation, The G. Unger Vetlesen Foundation, and Joe and Flinda Terteling.

\section{Literature Cited}

B ARIChello, N., ANd Mossop, D. 2011. The overwhelming influence of ptarmigan abundance on Gyrfalcon reproductive success in the central Yukon, Canada. In R. T. Watson, T. J. Cade, M. Fuller, G. Hunt, and E. Potapov (Eds.). Gyrfalcons and Ptarmigan in a Changing World. The Peregrine Fund, Boise, Idaho, USA. http://dx .doi.org/ 10.4080/gpcw.2011.0206

Bertelsen, A. 1921. The Birds of Umanaq District. (From Danish by W. G. Mattox). Meddelelser om Grønland 62:144-214.

Bertelsen, A. 1932. Reports about some of the more commonly occurring birds in West Greenland's Districts between 60 degrees and 77 degrees N.- particularly on their distribution, breeding areas, and migration. (From Danish by W. G. Mattox). Meddelelser om Grønland 91:28-31.

BLIss, L. C. 1979. Arctic heathlands. Pages 415-424 in R. L. Specht (Ed.). Heathlands and Related Shrublands of the World. A Descriptive Studies. Elsevier Scientific Publishing Company, Netherlands.
Boertmann, D. 2008. Grønlands Rødliste2007. (From Danish by D. Boertmann). Danmarks Miljøundersøgelser, Aarhus Universitet, og Grønlands Hjemmestyre.

Booms, T. L., AND M. R. Fuller. 2003. Gyrfalcon diet in central west Greenland during the nesting period. Condor 105:528-537.

Both, C., A. V. Artemyev, B. Blaauw, R. J. Cowie, A. J. Dekhuijzen, T. Eeva, A. EneMAR, L. Gustafsson, E. V. IVAnkina, A. JÄRVINEN, N. B. MetCALFe, E. I. NyHOLM, J. Potti, P. Ravussin, J. J. SAnz, B. SilVerin, F. M. Slater, L. V. Sokolov, J. TÖRÖK, W. WinkEL, J. Wright, H. ZANG, AND M. E. VisSER. 2004. Large-scale geographical variation confirms that climate change causes birds to lay earlier. Proceedings of the Royal Society B: Biological Sciences 271:1657-1662.

Broley, C. L. 1947. Migration and nesting of Florida Bald Eagles. Wilson Bulletin 59:320.

BURNHAM, K. K. 2008. Inter- and intraspecific variation of breeding biology, movements, and genotype in Peregrine Falcon Falco peregrinus and Gyrfalcon F. rusticolus populations in Greenland. D.Phil. dissertation, University of Oxford, Oxford, UK.

Burnham, K. K., W. A. Burnham, I. NEWTON, J. A. Johnson, And A. G. Gosler. (in press) The History and Range Expansion of Peregrine Falcons in the Thule Area, Northwest Greenland. Meddelelser om Grønland, Bioscience.

BurnhaM, W. A., K. K. Burnham, AND T. J. CADE. 2005. Past and present assessments of bird life in Uummannaq District, West Greenland. Dansk Ornithologisk Forenings Tidsskrift 99:196-208.

Burnham, W. A., and W. G. Mattox. 1984. Biology of the Peregrine and Gyrfalcon in Greenland. Meddelelser om Grønland, Bioscience 14:1-28.

CAвot, D., R. Goodwillie, And M. Viney. 1988. Irish Expedition of North-east Greenland 1987. Barnacle Books, Dublin, Ireland. 
CAdE, T. J. 1960. Ecology of the Peregrine and Gyrfalcon populations in Alaska. University of California Publications in Zoology 63:151-290.

Cade, T. J. 1982. The Falcons of the World. Comstock/Cornell University Press, Ithaca, New York, USA.

Cade, T. J., P. Koskimies, ANd O. K. Nielsen. 1998. Falco rusticolus Gyrfalcon. BWP Update, vol. 2, no. 1. Oxford University Press, Oxford, UK.

Chapman, F. M. 1899. Report on birds received through the Peary Expedition to Greenland. Bulletin of the American Museum of Natural History 12:219-244.

Cramp, S., AND K. E. L. Simmons (EDS.). 1980. Birds of the Western Palearctic, vol. 2. Oxford University Press, Oxford, UK.

Crick, H. Q. P., C. Dudley, D. E. Glue, AND D. L. THOMSON. 1997. UK birds are laying eggs earlier. Nature 388:526.

CRICK, H. Q. P., AND T. H. SPARKS. 1999. Climate change related to egg-laying trends. Nature 399:423-424.

DunN, P. O., AND D. W. Winkler. 1999. Climate change has affected the breeding date of Tree Swallows throughout North America. Proceedings of the Royal Society B: Biological Sciences 266:2,487-2,490.

Egevang, C., D. Boertmann, A. Mosbech, AND M. P. TAMstorf. 2003. Estimating colony area and population size of Little Auks Alle alle at Northumberland Island using aerial images. Polar Biology 26:813.

FENCKER, E. C. 1929. Nogle efterladte optegnelser om Nordgrønlands Fugle. Ved H. Fencker and H. Scheel. Dansk Ornithologisk Forenings Tidsskrift 23:33-50.

FleTCHER, D. J., AND K. WeBby. 1977. Observations on Gyrfalcons Falco rusticolus in northeast Greenland. Dansk Ornithologisk Forenings Tidsskrift 71:29-35.

Fowles, A. P. 1981. Gyrfalcon. Pages 169170 in A. D. Fox and D. A. Stroud (Eds.). Greenland White-fronted Goose Study: Report of the 1979 Expedition to Eqalungmiut Nunât, West Greenland. Greenland
White-fronted Goose Study, Aberystwyth, Wales, UK.

GudMUNDSSON, F. 1960. Some reflections on ptarmigan cycles in Iceland. Proceedings of the International Ornithological Congress 12:259-265.

Hagerup, A. T. 1891. The Birds of Greenland. Little, Brown, and Company, Boston, Massachusetts, USA.

HaLl, C. F. 1876. Narrative of the North Polar Expedition. US ship Polaris, Captain Charles Francis Hall commanding. Government Printing Office, Washington, DC, USA.

Herbert, R. A., ANd K. G. S. Herbert. 1965. Behavior of Peregrine Falcons in the New York City Region. Auk 82:62-94.

IPCC. 2007. Climate Change 2007: The Physical Science Basis. Contribution of Working Group I to the Fourth Assessment Report of the Intergovernmental Panel on Climate Change. S. Solomon, D. Qin, M. Manning, Z. Chen, M. Marquis, K. B. Averyt, M. Tignor, and H. L. Miller (Eds.). Cambridge University Press, Cambridge, UK and New York, New York, USA.

JENKINS, M. A. 1978. Gyrfalcon nesting behavior from hatching to fledging. Auk 95:122127.

JoHNSEN, P. 1953. Birds and mammals of Peary Land in north Greenland. Meddelelser om Grønland 128:1-135.

KосH, L. 1925. Nord om Grønland. København, Denmark.

LACK, D. 1954. The Natural Regulation of Animal Numbers. University Press, Oxford, UK.

LACK, D. 1966. Population Studies of Birds. University Press, Oxford, UK.

Manniche, A. L. 1910. The terrestrial mammals and birds of north-east Greenland. (From Danish by W. G. Mattox). Meddeleser om Grønland 45:183-187.

Matтox, W. G. 1970. Banding Gyrfalcons (Falco rusticolus) in Greenland, 1967. Bird Banding 41:31-37.

Mattox, W. G. 1998. High Arctic Institute and Greenland Peregrine Falcon Survey 
Progress Report 1998. The Peregrine Fund, Boise, Idaho, USA.

Mindell, D. P., J. L. B. Albuquerque, And C. M. White. 1987. Breeding population fluctuations in some raptors. Oecologia 72:328-388.

Mindell, D. P., AND C. M. White. 1988. Fluctuations of observed breeding Roughlegged Hawks and Gyrfalcons: Regularity reconsidered. Oecologia 77:14-18.

Moss, R., AND A. Watson. 2001. Population cycles in birds of the grouse family (Tetraonidae). In Advances in Ecological Research 32:53-111. Academic Press, London, UK.

Mossop, D. H. 2011. Long-term studies of Willow Ptarmigan and Gyrfalcon in the Yukon Territory: A collapsing 10-year cycle and its apparent effect on the top predator. In R. T. Watson, T. J. Cade, M. Fuller, G. Hunt, and E. Potapov (Eds.). Gyrfalcons and Ptarmigan in a Changing World. The Peregrine Fund, Boise, Idaho, USA. http://dx.doi.org/10.4080/gpcw.2011.0206

Mossop, D. H., AND R. HAYES. 1982. The Yukon Territory Gyrfalcon harvest experiment (1974-80). Pages 263-280 in W. N. Ladd and P. F. Schempf (Eds.). Proceedings, Symposium and Workshop: Raptor Management and Biology in Alaska and Western Canada. US Fish and Wildlife Service, Anchorage, Alaska, USA.

Mossop, D. H., AND R. HAYES. 1994. Long term trends in the breeding density and productivity of Gyrfalcon Falco rusticolus in the Yukon Territory, Canada. Pages 403413 in B. -U. Meyburg and R. D. Chancellor (Eds.). Raptor Conservation Today. Helm Information Inc, Mountfield, East Sussex, UK.

Mountain, K. R., D. A. Howarth, And S. R. Joule. 2001. Spatial and temporal temperature change in the arctic basin since 1994: Assessment of localized short-term data sets. Polar Geography 25:1-21.

Newton, I. 1979. Population Ecology of Raptors. T. \& A. D. Poyser, London, UK.
Newton, I. 1998. Population Limitations in Birds. Academic Press, London, UK.

Newton, I., AND M. MARQuiss. 1984. Seasonal trend in the breeding Performance of Sparrowhawks. Journal of Animal Ecology 53:809-829.

NiELSEN, Ó. K. 1999. Gyrfalcon predation on ptarmigan: Numerical and functional responses. Journal of Animal Ecology 68:1034-1050.

NiElsen, Ó. K., AND T. J. CADE. 1990. Seasonal changes in food habits of Gyrfalcons in NE-Iceland. Ornis Scandinavica 21:202211.

NySTRÖM, J., J. EKENSTEDT, J. ENGSTRÖM, AND A. AngerbJöRn. 2005. Gyr Falcons, ptarmigan and microtine rodents in northern Sweden. Ibis 147:587-597.

Platt, J. B. 1977. The breeding behavior of wild and captive Gyrfalcons in relation to their environment and human disturbance. Ph.D. dissertation, Cornell University, Ithaca, New York, USA.

Poole, K. G., AND R. G. BRomley. 1988. Natural history of the Gyrfalcon in the central Canadian Arctic. Arctic 41:31-38.

Potapov, E., ANd R. SAle. 2005. The Gyrfalcon. Yale University Press, New Haven, Connecticut, USA.

RAFN, A. 1933. Lidt om fuglene I og omkring Julianehaab. Dansk Ornithologisk Forenings Tidsskrift 27:19-25.

RatClifFe, D. A. 1969. Population trends of the Peregrine Falcon in Great Britain. Pages 239-269 in J. J. Hickey (Ed.). Peregrine Falcon Populations: Their Biology and Decline. University Press, Madison, Wisconsin, USA.

RedPATH, S. M., ANd S. J. ThiRgood. 1999. Numerical and functional responses of generalist predators: Harriers and Peregrines on grouse moors. Journal of Animal Ecology 68:879-892.

Rosenfield, R. N., J. W. Schneider, J. M. Papp, AND W. S. Seegar. 1995. Prey of Peregrine Falcons breeding in West Greenland. Condor 97:763-770. 
SAbine, E. 1819. A memoir on the birds of Greenland; with descriptions and notes on the species observed in the late voyage of discovery in Davis's Straits and Baffin's Bay. Transactions of the Linnean Society 12:527-559.

Salomonsen, F. 1950. Grønlands Fugle/The Birds of Greenland. Ejnar Munksgaard, Copenhagen, Denmark.

SELÅs, V. 1998. Does food competition from Red Fox (Vulpes vulpes) influence the breeding density of Goshawk (Accipiter gentilis)? Evidence from a natural experiment. Journal of Zoology 246:325-335.

Serreze, M. C., J. E. WALSh, F. S. Chapin III, T. Osterkamp, M. Dyurgerov, V. Romanovsky, W. C. Oechel, J. Morison, T. ZHANG, AND G. BARRY. 2000. Observational evidence of recent change in the northern high-latitude environment. Climatic Change 46:59-207.

Shank, C. C., AND K. G. Poole. 1994. Status of Gyrfalcon Falco rusticolus populations in the Northwest Territories, Canada. Pages 421-436 in B.-U. Meyburg and R. D. Chancellor (Eds.). Raptor Conservation Today. Helm Information Inc, Mountfield, East Sussex, UK.

STONE, W. 1895. List of birds collected in north Greenland by the Peary expedition of 1891-92 and the relief expedition of 1892.
Proceedings of the Academy of Natural Sciences of Philadelphia 47:502-505.

Tordoff, H. B., AND P. T. Redig. 1997. Midwest Peregrine Falcon demography, 19821995. Journal of Raptor Research 31:339-346.

VIBE, C. 1967. Arctic animals in relation to climatic fluctuations. The Danish Zoogeographical Investigations in Greenland. Meddelelser om Grønland 170:1-227.

WALKER, D. 1860. The last arctic expedition under Captain Sir F. L. M'Clintock, R. N. Journal of the Royal Dublin Society 3:6177.

Watson, A., R. Moss, And S. RaE. 1998. Population dynamics of Scottish Rock Ptarmigan cycles. Ecology 79:1174-1192.

Weeden, R. B., And J. B. Theberge. 1972. The dynamics of a fluctuating population of ptarmigan in Alaska. Proceedings of the International Ornithological Congress 15:90-106.

White, C. M., AND T. J. CADE. 1971. Cliffnesting raptors and ravens along the Colville river in arctic Alaska. Living Bird 10:107-150.

Whitfield, P. H., A. W. Hall, and A. J. CANNON. 2004. Changes in the seasonal cycle in the circumpolar Arctic, 1976-95: Temperature and precipitation. Arctic 57:80-93. 


\section{- BuRnhAM AND BURNHAM -}

